\title{
Application of Input-Output Table for Structural Analysis of the Nation's Economy: A Case of Mongolia
}

\author{
N. Tungalag, B. Unenbat, L. Oyuntsetseg, R. Enkhbat* \\ National University of Mongolia, Mongolia \\ Received October 6, 2019; Revised October 25, 2019; Accept October 29, 2019
}

Copyright $(2019$ by authors, all rights reserved. Authors agree that this article remains permanently open access under the terms of the Creative Commons Attribution License 4.0 International License

\begin{abstract}
The Leontief Input-Output model is a valuable tool for economics. Many economic research works are devoted to analysis of Input-Output table [1]-[5]. In this paper, we consider a separation of Copper production subsector from Mining of metal ores sector which is one of the 55 economic sectors of Input-Output Table of Mongolia. We examine impact of this subsector on other economic sectors using Input-Output table for 2016 and Physical Measurement Method of Cost Accounting [6]. We compute input coefficients of new extended matrix as well as inverse coefficients.
\end{abstract}

Keywords Input Output Table, Leontief Model, Economic Sectors

\section{Introduction}

Wassily Leontief (1973) created an Input-Output model for economics. His model is a basic for more models currently being used in many parts of economics. This model can be applied to any size of economy from a small business to the whole world. The main goal of the Leontief Input-Output model is to balance the total amount of goods produced to the total demand for that production. Input-Output model uses Input-Output Table (IOT) which is used for many economic and political purposes. IOT is mainly used in the following.

- IOT represents manageable information for policy makers.

- $\quad$ IOT differ from all other methodological approaches because they show also indirect repercussions of governmental policy-making.

- The consistency of detailed IOT and their full integration into National Accounts offers insight into micro-economic and macro-economic facts of the whole economy at the same time.
- Politicians can use the inter relations between the various quadrants of the IOT to anticipate the implications of their measures taken.

- Based on IOT the structural analysis of economy can be done.

\section{Open Static Quantity Models}

The method that the Leontief Input-Output model uses is the linear algebra. The nation's economy is divided into $n$ sectors that produce goods and services.

There exists a production vector $x$ which is the output. There is also the final demand vector $y$ which is the value of the goods and services demanded. For each sector there is a unit consumption vector which lists the inputs needed per unit of output of the sector. The consumption vectors together form a consumption matrix $A$. This matrix is also called matrix of input coefficients.

The system of linear equations for the open static input-output model in its quantity version can be defined in matrix terms as

$$
\begin{gathered}
X=A X+Y \\
(E-A) X=Y,
\end{gathered}
$$

where

$$
A=\left(\begin{array}{cccc}
a_{11} & a_{12} & \ldots & a_{1 n} \\
a_{21} & a_{22} & \ldots & a_{2 n} \\
\ldots & \ldots & \ldots & \ldots \\
a_{n 1} & a_{n 2} & \ldots & a_{n n}
\end{array}\right), X=\left(\begin{array}{c}
x_{1} \\
x_{2} \\
\vdots \\
x_{n}
\end{array}\right), Y=\left(\begin{array}{c}
y_{1} \\
y_{2} \\
\vdots \\
y_{n}
\end{array}\right)
$$

$X$ is column vector of technology dependent production made up of elements

$$
x_{1}, x_{2}, \ldots x_{n} .
$$

$Y$ is column vector of system independent final demand made up of elements

$$
y_{1}, y_{2}, \ldots y_{n}
$$

$A$ is a matrix of input coefficients with the elements $a_{i j}$, 
$\mathrm{E}$ is the unit matrix. The input coefficient of industry $j$ are defined as

$$
a_{i j}=\frac{x_{i j}}{x_{j}},
$$

$x_{j}$ - total output of industry $j$,

$x_{i j}-$ is the quantity of industry $i$ demanded for producing the quantity $x_{j}$

The input coefficients can be interpreted as the shares of costs for goods, services and primary inputs in total output.

The solution to system (2) can be defined in the following.

$$
X=(E-A)^{-1} Y
$$

Denote by $S$ Leontief inverse matrix:

$$
\begin{gathered}
X=(E-A)^{-1} Y, S=(E-A)^{-1}, \\
X=S Y .
\end{gathered}
$$

The system (4) can be written also in the form:

$$
\begin{aligned}
& \left(\begin{array}{c}
x_{1} \\
x_{2} \\
\vdots \\
x_{n}
\end{array}\right)=\left(\begin{array}{cccc}
s_{11} & s_{12} & \ldots & s_{1 n} \\
s_{21} & s_{22} & \ldots & s_{2 n} \\
\ldots & \ldots & \ldots & \ldots \\
s_{n 1} & s_{n 2} & \ldots & s_{n n}
\end{array}\right)\left(\begin{array}{c}
y_{1} \\
y_{2} \\
\vdots \\
y_{n}
\end{array}\right) \\
& x_{i}=\sum_{j=1}^{n} s_{i j} y_{j}, i=1,2, \ldots, n
\end{aligned}
$$

If we put $y_{k}=1$ and $y_{j}=0, j \neq k$ then we have

$$
x_{i}=s_{i k} i=1,2, \ldots, n
$$

It means that the inverse coefficients indicate how much production sector $i$ must produce in order to satisfy one unit of final demand for goods and services from production sector $k$.

The coefficients of the inverse Leontief matrix can be used also to evaluate different interrelations within the consistent framework of an IOT for policy-oriented diagnosis. On the other hand, it can be easily checked that

$$
\Delta X=S \Delta Y,
$$

where $\quad \Delta X=\left(\Delta x_{1}, \Delta x_{2} \ldots, \Delta x_{n}\right)^{T}$

$$
\Delta Y=\left(\Delta y_{1}, \Delta y_{2} \ldots, \Delta y_{n}\right)^{T}
$$

System (7) implies that

$$
\Delta x_{i}=\sum_{j=1}^{n} s_{i j} \Delta y_{j} i=1,2, \ldots, n
$$

In a particular, if we set $\Delta y_{i}=1, j=1,2, \ldots, n$ then from (8) we have

$$
\Delta x_{i}=\sum_{j=1}^{n} s_{i j}, i=1,2, \ldots, n .
$$

A production sector in IOT includes subsectors which should be analyzed separately. Therefore, it is important to investigate impacts of these subsectors on a rest of production sectors. In other words, we need to do structural and impact analysis for IOT. Assume that production sector $p$ includes products of $k$ sectors. It means that the following conditions are satisfied.

$$
\mathrm{x}_{i}=\sum_{j=0}^{n} x_{i j}+\sum_{j=n+1}^{n+k} x_{i j}, i=1,2, \ldots, n+k,
$$

$$
\begin{gathered}
\mathrm{x}_{p}=\sum_{i=1}^{n+k} x_{i p}, \\
\mathrm{x}_{n+j}=\sum_{i=1}^{n+k} x_{i n+j} \\
\sum_{i=1}^{n} y_{i}=\sum_{\substack{i=1 \\
i \neq p}}^{n} y_{i}+\sum_{j=n+1}^{n+k} y_{j}
\end{gathered}
$$

As a result, a new IOT can be computed and extended in the following:

$$
\begin{gathered}
\tilde{a}_{i j}=\frac{\tilde{x}_{i j}}{\tilde{x}_{j}}, i=\overline{1, n+k} j=\overline{1, n+k} \\
\tilde{A}=\left\{\tilde{x}_{i j}\right\}_{(n+k) x(n+k)}, \tilde{X}=\left\{\tilde{x}_{i j}\right\},
\end{gathered}
$$

For the extended matrix $\tilde{A}$, system (1) can be written as

$$
\begin{gathered}
\tilde{X}=\tilde{A} \tilde{X}+\tilde{Y} \\
\tilde{X}=\left(\begin{array}{c}
\tilde{x}_{1} \\
\tilde{x}_{2} \\
\vdots \\
\tilde{x}_{n+k}
\end{array}\right), \tilde{Y}=\left(\begin{array}{c}
\tilde{y}_{1} \\
\tilde{y}_{2} \\
\vdots \\
\tilde{y}_{n}
\end{array}\right) .
\end{gathered}
$$

A solution $\tilde{X}$ of system (10) is computed as

$$
\begin{gathered}
\tilde{X}=(\tilde{E}-\tilde{A})^{-1} \tilde{Y}, \\
\tilde{S}=(\tilde{E}-\tilde{A})^{-1}, S=\left\{\tilde{S}_{i j}\right\}_{(n+k) x(n+k)} \\
\tilde{X}=\tilde{S} \tilde{Y} .
\end{gathered}
$$

The elements of extended input matrix $\tilde{A}$ are:

$$
\tilde{a}_{i j}=\frac{\tilde{x}_{i j}}{\tilde{x}_{j}}, i=\overline{1, n} ; j=n+p, 1 \leq p \leq k
$$

In order to find production quantity of sector $i$ to satisfy one unit of final demanded good from production $\operatorname{sector}(n+j)$, we put

$$
\tilde{x}_{i j}=\tilde{s}_{i n+j}, 1 \leq j \leq k .
$$

Impacts of products of new appeared sectors on other sectors are calculated as:

$$
\Delta \tilde{x}_{i}=\sum_{j=1}^{n+k} \tilde{s}_{i j} \Delta \tilde{y}_{j}
$$

If we are interested only in one sector $(n+k)$, then we have $\Delta \tilde{y}_{j}=0, j \neq n+k$ and

$$
\Delta \tilde{x}_{i}=\tilde{s}_{i(n+k)} \Delta \tilde{y}_{j} .
$$

\section{Numerical Results}

We have identified the role of some final categories for individual production sectors based on structural analysis and impact analysis. For instance, using decomposition method we have separated the copper production subsector from the Mining of metal ores sector so that we can see impacts of the sector on other sectors. Initially, we have used the following statistical data of Mongolian economy. 
Table 1. INPUT - OUTPUT TABLE OF MONGOLIA (55x55), 2016, mln.tog

\begin{tabular}{|c|c|c|c|c|c|c|c|c|}
\hline No & Industries & $\begin{array}{c}\text { Crop } \\
\text { production, } \\
\text { related service } \\
\text { activities }\end{array}$ & $\begin{array}{l}\text { Animal } \\
\text { production, } \\
\text { hunting }\end{array}$ & $\begin{array}{l}\text { Forestry } \\
\text { and } \\
\text { logging }\end{array}$ & $\begin{array}{l}\text { Mining of } \\
\text { metal ores }\end{array}$ & & $\begin{array}{l}\text { INTERMEDIATE } \\
\text { USE }\end{array}$ & FINAL USE \\
\hline $\mathrm{A}$ & $\mathrm{C}$ & 1 & 2 & 3 & 4 & $\ldots 55$ & 56 & 65 \\
\hline 1 & $\begin{array}{c}\text { Crop } \\
\text { production, } \\
\text { related service } \\
\text { activities }\end{array}$ & 117540.3 & 147419.3 & 17159.6 & 2133.6 & & 437095.2 & 291907.9 \\
\hline 2 & $\begin{array}{c}\text { Animal } \\
\text { production, } \\
\text { hunting }\end{array}$ & 6911.3 & 42938.9 & 83.4 & 5930.1 & & 1190925.8 & 2272756.1 \\
\hline 3 & $\begin{array}{c}\text { Forestry and } \\
\text { logging }\end{array}$ & 9080.7 & 11382.2 & 1326.3 & 149.4 & & 40259.5 & 57706.2 \\
\hline 4 & $\begin{array}{l}\text { Mining of metal } \\
\text { ores }\end{array}$ & 670.7 & 638.8 & 15.6 & 15950.8 & & 58999.8 & 5832282.9 \\
\hline$\ldots$ & & & & & & & & \\
\hline \multicolumn{9}{|l|}{55} \\
\hline 56 & $\begin{array}{l}\text { Domestic } \\
\text { intermediate } \\
\text { consumption }\end{array}$ & 293466.6 & 686294.0 & 35760.8 & 1661134.0 & & 13767383.8 & 28749316.4 \\
\hline
\end{tabular}

Source: [7] National Statistical Office of Mongolia

Table 2. Input, output Coefficients of Mining of metal ores

\begin{tabular}{|c|c|c|c|c|c|c|c|}
\hline No & Industries & $\begin{array}{l}\text { Crop production, } \\
\text { related service } \\
\text { activities }\end{array}$ & $\begin{array}{c}\text { Animal } \\
\text { production, } \\
\text { hunting }\end{array}$ & $\begin{array}{c}\text { Forestry } \\
\text { and logging }\end{array}$ & $\begin{array}{l}\text { Mining of } \\
\text { metal ores }\end{array}$ & & $\begin{array}{l}\text { INTERMEDIATE } \\
\text { USE }\end{array}$ \\
\hline A & $\mathrm{C}$ & 1 & 2 & 3 & 4 & $\ldots 55$ & 56 \\
\hline 1 & $\begin{array}{l}\text { Crop production, } \\
\text { related service } \\
\text { activities }\end{array}$ & & & & 0.13 & & \\
\hline 2 & $\begin{array}{l}\text { Animal production, } \\
\text { hunting }\end{array}$ & & & & 0.36 & & \\
\hline 3 & Forestry and logging & & & & 0.01 & & \\
\hline 4 & $\begin{array}{l}\text { Mining of metal } \\
\text { ores }\end{array}$ & 1.14 & 1.08 & 0.03 & 27.4 or 0.96 & $\cdots$ & 100.00 \\
\hline & & & & & 0.01 & & \\
\hline$\ldots$ & & & & & & & \\
\hline 55 & & & & & $\ldots$ & & \\
\hline 56 & $\begin{array}{c}\text { Domestic } \\
\text { intermediate } \\
\text { consumption }\end{array}$ & & & & 100.00 & & \\
\hline
\end{tabular}

Source: Calculated by authors using data of National Statistical Office of Mongolia

As we can see from table 1, domestic intermediate consumption of Mining and metal ores sector is $1,666,134.0 \mathrm{mln} . \operatorname{tog}$. and intermediate use of this sector is $58,99.8$ mln.tog. Based on initial IOT of Mongolia from 2016, we calculated input and output coefficients of Mining and metal ores sector by well-known method of IOT analysis.

Input coefficients are calculated by dividing each entry of the input-output table by the corresponding column total and can be interpreted as the shares of costs for goods, services and primary inputs in total output. Output coefficients are calculated by dividing each entry of the input-output table by the corresponding row total and can be interpreted as the shares in total output (revenues) or market shares for commodities (domestic and imported) and for primary inputs.
In Mining and metal ores sector included Copper mining subsector which is one of important sectors of Mongolian economy and should be analyzed separately. As average from 2014 to 2017, 68 percent of Government revenues and 18 percent of GDP come from copper mining. In order to separate this sector in IOT we propose to use a Physical Measurement Method of Cost Accounting and Input and output coefficients of Mining of metal ores sector of IOT.

As we know I quadrant of IOT is an interrelation between domestic intermediate consumption and intermediate production use.

By the Physical Measurement Method joint costs are allocated based on number of units or physical quantity of each product relative to total production. In our case we used share of copper of $38.08 \%$ for 2016 . 
Table 3. SHARE OF COPPER PRODUCTION IN METAL ORES PROCESSING

\begin{tabular}{|c|c|c|c|}
\hline No & Metal ores processing & 2016, thous.tn & $\%$ \\
\hline 1 & Copper & $1,445.10$ & $\mathbf{3 8 . 0 8}$ \\
\hline 2 & Molybdenum concentrate & 5.20 & 0.14 \\
\hline 3 & Gold & 0.02 & 0.00 \\
\hline 4 & Concentrate fluoride & 34.10 & 0.90 \\
\hline 5 & Iron ore concentrate & $2,209.90$ & 58.24 \\
\hline 6 & Zinc Concentrate & 100.20 & 2.64 \\
\hline
\end{tabular}

Source: [8] https://www.mrpam. gov.mn/, Minerals and Petroleum Authority, Statistical information, 2016

Table 4. INPUT - OUTPUT TABLE WITH SEPARETED SUBSECTOR, 2016, mln.tog, (56x56), 2016, mln.tog

\begin{tabular}{|c|c|c|c|c|c|c|c|c|c|}
\hline No & Industries & $\begin{array}{c}\text { Crop } \\
\text { production, } \\
\text { related } \\
\text { service } \\
\text { activities }\end{array}$ & $\begin{array}{l}\text { Animal } \\
\text { production, } \\
\text { hunting }\end{array}$ & $\begin{array}{l}\text { Forestry } \\
\text { and } \\
\text { logging }\end{array}$ & $\begin{array}{l}\text { Mining of } \\
\text { metal ores }\end{array}$ & $\begin{array}{l}\text { Copper } \\
\text { mining }\end{array}$ & & $\begin{array}{c}\text { INTERME-DIATE } \\
\text { USE }\end{array}$ & FINAL USE \\
\hline A & $\mathrm{C}$ & 1 & 2 & 3 & 4 & 5 & $\ldots 56$ & 57 & 66 \\
\hline 1 & $\begin{array}{c}\text { Crop } \\
\text { production, } \\
\text { related service } \\
\text { activities }\end{array}$ & 117540.3 & 147419.3 & 17159.6 & 1323.0 & 811.08 & $\cdots$ & 437095.2 & 291907.9 \\
\hline 2 & $\begin{array}{c}\text { Animal } \\
\text { production, } \\
\text { hunting }\end{array}$ & 6911.3 & 42938.9 & 83.4 & 2052.0 & 3877.8 & $\ldots$ & 1190925.8 & 2272756.1 \\
\hline 3 & $\begin{array}{c}\text { Forestry and } \\
\text { logging }\end{array}$ & 9080.7 & 11382.2 & 1326.3 & 52.0 & 97.7 & $\cdots$ & 40259.5 & 57706.2 \\
\hline 4 & $\begin{array}{l}\text { Mining of metal } \\
\text { ores }\end{array}$ & 416.0 & 396.8 & 9.6 & 5521.8 & 10,430 & $\cdots$ & 36579.8 & 3616015.0 \\
\hline 5 & Copper mining & 255.0 & 243.0 & 6.0 & $9,808.0$ & $6,143.0$ & $\ldots$ & $22,420.0$ & $2,216,267.0$ \\
\hline \multicolumn{10}{|l|}{$\ldots$} \\
\hline \multicolumn{10}{|l|}{56} \\
\hline 57 & $\begin{array}{c}\text { Domestic } \\
\text { intermediate } \\
\text { consumption }\end{array}$ & 293466.6 & 686294.0 & 35760.8 & 1029903.0 & $631,231.0$ & $\cdots$ & 13767383.8 & 28749316.4 \\
\hline
\end{tabular}

Source: [7] National Statistical Office of Mongolia

As a result we can analyze new $56^{\text {th }}$ copper production sector impacts on other 55 sectors. In this way we can analyze each subsector in a question, extending IOT by separating subsectors.

\section{Conclusions}

Copper mining sector plays an important role in Mongolian economy. We have investigated impacts of Copper production subsector on other production sectors of the economy. In order to do it we have separated this sector from Mining of metal ores sector using physical measurement method of accounting, based on input and output coefficients. We have shown that it also other $k$ sectors from IOT can be separated by extending the original IOT.

\section{Acknowledgements}

This work was supported by a project of the Business School of National University of Mongolia.

\section{REFERENCES}

[1] Thijs Ten Raa, Input-output economics: theory and applications: featuring Asian economies, World Scientific, 2009

[2] Xinhao Wang, Rainer vom Hofe, Research Methods in Urban and Regional Planning, Springer, 2007

[3] S.M. NASEEM, Application of Input-Output Analysis in Pakistan, Economic Digest Vol. 3, No. 2 
[4] Wassily Leontief, Why Economics Needs Input-Output Analysis, Challenge Vol. 28, No. 1, 1985

[5] Wassily Leontief, Input-Output Analysis, The New Palgrave Dictionary of Economics, 2nd edition, 2008.

[6] Mitra J.K, Advanced Cost Accounting, New age International publishers, 2009

[7] www.1212.mn

[8] Minerals and Petroleum Authority of Mongolia, 01.06.2019, [Online], Available: https://mrpam.gov.mn. 